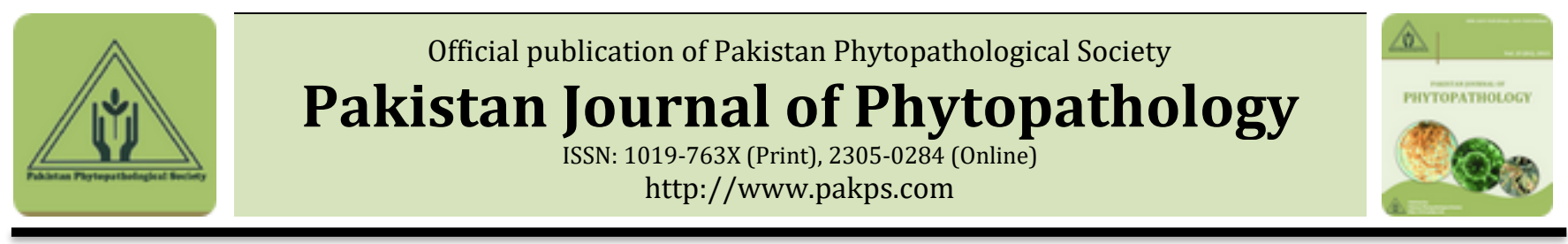

\title{
SENSITIVITY ASSESSMENT OF SOIL-BORNE PATHOGENS TO ETHANOLIC AND METHANOLIC LEAF EXTRACT OF CHROMOLAENA ODORATA (L.) USING DILUTION AND DIFFUSION ASSAY METHODS
}

\author{
Augusta Okoro*, Chiemeka Onaebi \\ Department of Plant Science and Biotechnology (Plant Pathology Unit), University of Nigeria, Nigeria.
}

A B S T RA C T

The sensitivity of pure isolates of Phytophthora colocasiae and Fusarium oxysporum to methanolic and ethanolic leaf extracts of $C$. odorata was evaluated using diffusion(agar and disc diffusion) and dilution(broth and agar dilution) assays. Basic quantitative and qualitative analyses of the extracts were determined. The experiment was laid out as factorial in Completely Randomized Design (CRD) with three replications. Data collected were adequately analyzed using Univariate approach and Least Significance Difference (LSD) test to separate significant at $\mathrm{P} \leq 0.05$. Observations from the study revealed that antimicrobial activities of the plant extracts were dependent upon the assay methods used which varied significantly. Ethanolic leaf extracts of $C$. odorata significantly increased the inhibition zone diameter (IZD) against $F$. oxysporum when compared to methanolic leaf extracts of same plant. However, significant differences were not observed in IZD between ethanolic and methanolic leaf extracts against $P$. colocasiae $(12.67 \pm 0.79$ and $12.56 \pm 0.74)$. Ethanolic extracts of $C$. odorata were found to possess higher inhibitory effects shown by the wider inhibition zone against the pathogens using disc diffusion assay. There were significant and non- significant reductions respectively in IZD of $F$. oxysporum and $P$. colocasiae with increased concentrations of the leaf extracts. The methanolic and ethanolic extracts of $C$. odorata showed significant higher inhibitory activities against the pathogens at MICof 6.25 and $25 \mathrm{mg} / \mathrm{ml}$ respectively, inhibiting the growth of the pathogens completely.

Keywords: Antimicrobial; Medicinal plants; Phytochemistry; Assay; Phytophthora colocasiae; Fusarium oxysporum.

\section{INTRODUCTION}

Fungi are a very useful class of microorganisms which mostly includes saprophytes, which live on dead organic (material) (Joshi et al., 2013). Many diseases caused by fungi in plants are responsible for yield losses in numerous economically important crops (Gawai, 2015). Soil-borne diseases are caused by a diverse group of fungi and related organisms which persist in the soil matrix and in residues on the soil surface. The most important soil borne pathogens genera include Pythium, Phytophthora, Rhizoctonia and Fusarium. Phytophthora and Fusarium are among the predominant soil borne

Submitted: April 04, 2020
Revised: June 04, 2020
Accepted for Publication: June 06,2020
* Corresponding Author:
Email: augusta.obiekwe@unn.edu.ng
(C) 2017 Pak. J. Phytopathol. All rights reserved.

pathogens (Rani and Sudini, 2013).

Soil-borne diseases are difficult to control because they are caused by pathogens which can survive for long periods in the absence of the normal crop host, and often have a wide host range including weeds (Rani and Sudini, 2013). Generally, phytopathogenic fungi are controlled by synthetic fungicides. However, these chemical fungicides are not readily biodegradable, they tend to persist for years in the environment and a few fungi have developed resistance to them (Ramaiah and Garampalli, 2015).

Plants contain thousands of constituents which are valuable sources of new and biologically active molecules possessing antimicrobial property (Gurjar et al., 2012). A precise evaluation of fungal sensitivity to plant extract is pivotal for the successful management of fungal diseases and to the relative analysis of antimicrobial agents. The lack of standardized in vitro methods for testing antimicrobial activities of plant crude extracts has led to variations in 
results between research groups. Many problems associated with this research area lies on the various methods used in the extraction of plants and antimicrobial assessment (Othman et al., 2011). Owing to the rapid increase in fungal infections and the new attraction to the properties of new antimicrobial products, it is important to develop rapid and accurate methods of antifungal susceptibility assay for screening and quantifying the antimicrobial effect of an extract for its applications in human health; to increase safety of the food to the populace, agriculture and the environment (Balouiri et al., 2016). These antimicrobial activities of various plant extracts are scientifically proved (Sousa et al., 2012). In the present study, agar dilution, broth dilution, agar well diffusion and disc diffusion assays were evaluated for susceptibility of fungi (Phytophthora colocasiae and Fusarium oxysporum) to C. odorata. The efficacy of these methods was compared in order to determine the assay method with the most significant effect and to obtain a simple test to evaluate antimicrobials from leaf (extract).

\section{MATERIALS AND METHODS}

Collection of samples: The leaves of $C$. odorata were collected from Botanic Garden of the Department of Plant Science and Biotechnology, University of Nigeria, Nsukka and confirmed at the Herbarium of the Department of Plant Science and Biotechnology. This study was carried out in Plant Pathology Laboratory, Department in the same Department.

Preparation of sample: Fresh leaves of $C$. odorata collected were washed with tap water and rinsed with sterile distilled water. Then kept dry under room temperature for two weeks, after which they were ground into fine powder and kept in sealed containers for extraction.

Extraction and Phytochemical analysis procedure: The extraction was carried out using modified soaking methods as described by Doherty et al. (2010).The ethanolic and methanolic extract of the plants were prepared by soaking $100 \mathrm{~g}$ of the ground plant samples in 1,000 $\mathrm{ml}$ of absolute ethanol and methanol respectively. The suspension was left overnight for 24 hours before filtering with No. 1 Whatman filter paper and concentrated using a rotary evaporator leaving behind the crude extracts. The crude extracts were collected in a sterile $1000 \mathrm{ml}$ round bottom flask and stored in a refrigerator at $12^{\circ} \mathrm{C}$ until required.

The presence of biological active ingredients (alkaloid, saponin, tannins, flavonoid, terpenoids, tannins, steroids, hydrogen cyanides, phenols and glycoside) in the leaf extracts was investigated using different standard methods as described by (Anukworji et al., 2016 and Doherty et al. 2010)

Reconstitution of the Extract: The method described by Eze and Ezejiofor (2014) was used to reconstitute the Extract by dissolving the extract in $20 \%$ concentration of Dimethyl Sulphoxide (DMSO) (JHD, China) in the ratio of 1:10 (1g of crude extract dissolved in $10 \mathrm{ml}$ of DMSO) to give a concentration of $100 \mathrm{mg} / \mathrm{ml}$. Other concentrations of $50 \mathrm{mg} / \mathrm{ml}, 25 \mathrm{mg} / \mathrm{ml}, 12.5 \mathrm{mg} / \mathrm{ml}$ and $6.25 \mathrm{mg} / \mathrm{ml}$ were made from the stock concentration $(100 \mathrm{mg} / \mathrm{ml})$. Control plates containing $0.1 \mathrm{ml}$ of $32 \mathrm{mg} / \mathrm{l}$ Fluconazole served as positive control while $1 \mathrm{ml}$ of $20 \%$ DMSO served as negative control.

Preparation of culture media: Potato Dextrose Agar (PDA) (Titam biotech, India) was used for both culturing and sub-culturing of fungi to obtain pure cultures while Muller Hinton Agar ((MHA) Titam biotech, India) was used for Disc diffusion, Agar well diffusion and Dilution assay. Following the modified method of Kalpana et al. (2013), MHA was prepared by dissolving $39 \mathrm{~g}$ of the commercially available Muller Hinton Agar in $1000 \mathrm{ml}$ of distilled water. The dissolved powder was autoclaved at $103 \mathrm{KNM}^{-2}$ for 15 minutes at $121^{\circ} \mathrm{C}$. The autoclaved medium was mixed thoroughly and poured into sterile Petri dishes approximately $25 \mathrm{ml}$ and allowed to set at ambient temperature until when required. Potato Dextrose Agar (PDA) was dissolved in $500 \mathrm{ml}$ of water by boiling at the same time. The filtrate of potato broth was poured into the agar and dextrose was added and the volume restored to $1000 \mathrm{ml}$ with sterile distilled water. The medium were poured into two $500 \mathrm{ml}$ conical flasks and test tubes plugged with cotton wool and sterilized by autoclaving at $103 \mathrm{KNM}^{-2}$ pressures for 20 minutes at $121{ }^{\circ} \mathrm{C}$. The medium was allowed to cool and $200 \mu \mathrm{g}$ of Chloramphenicol was added. The medium were poured aseptically into sterile Petri dishes and allowed to solidify.

Sources and isolation of test organisms: Diseasedtaro leaves for the isolation of Phytophthora colocasiaewas collected and confirmed at the herbarium unit of the Federal University of Agriculture, Umudike, while Fusarium oxysporum was collected from Plant Pathology Laboratory, Department of Plant Science and Biotechnology, University of Nigeria, Nsukka.The organisms were maintained on Potato Dextrose Agar (PDA) at $12^{\circ} \mathrm{C}$ and constantly revived on fresh PDA plates.

The isolation technique described by Chiejina (2008) was used for the fungal isolation while identification of fungal 
isolates was based on their macroscopic and microscopic features, then confirmed with the aid of standard mycological identification texts by Agrios (2005) and Dugan (2017). Inoculum preparation was performed according to the method of Ohikhena et al. (2017).

Determination of $F$. oxysporum and $P$. colocasiae sensitivity to methanolic and ethanolic extracts of $C$. odorata using dilution and diffusion methods: Four assay methods were employed for the antifungal screening of the plant extracts. The Disc diffusion assay and Agar well diffusion assay were used to measure the inhibition zone diameter of the extracts (Bukar et al., 2010; Doherty et al., 2010; Pachkore et al., 2011) while agar dilution and broth dilution assays, according to the methods of Ohikhena et al. (2017) were used to determine the MICs of the extracts. The minimum extract concentration that inhibited the growth of the pathogens will be taken to be the minimum inhibitory concentration.

Table 1. Phytocher

\begin{tabular}{|c|c|c|c|c|c|}
\hline \multirow{2}{*}{ Phytochemical (mg/100 g) } & \multicolumn{2}{|c|}{ Qualitative Screening } & \multicolumn{2}{|c|}{ Quantitative Screening } & \multirow[b]{2}{*}{ t-value } \\
\hline & Ethanolic extract & Methanolic extract & Ethanolic extract & Methanolic extract & \\
\hline Terpenoids & + & + & $884.45 \pm 0.22$ & $904.72 \pm 3.15$ & $-6.42^{* *}$ \\
\hline Tannins & +++ & +++ & $2205.27 \pm 0.03$ & $2414.34 \pm 0.00$ & $-7174.25^{* * *}$ \\
\hline Alkaloids & ++ & ++ & $331.01 \pm 0.38$ & $332.78 \pm 0.01$ & $-4.71^{* *}$ \\
\hline Saponins & + & + & $1.22 \pm 0.00$ & $1.89 \pm 0.00$ & $-144.500^{* * *}$ \\
\hline Steroids & + & + & $0.67 \pm 0.02$ & $1.13 \pm 0.00$ & $-21.042^{* *}$ \\
\hline $\mathrm{HCN}$ & + & + & $2.11 \pm 0.06$ & $2.12 \pm 0.00$ & $-.049^{\mathrm{NS}}$ \\
\hline Flavonoids & ++ & ++ & $532.60 \pm 0.04$ & $646.93 \pm 0.01$ & $-2996.72^{* * *}$ \\
\hline Phenols & ++ & ++ & $1094.17 \pm 0.50$ & $1217.19 \pm 0.01$ & $-2446.29 * * *$ \\
\hline Glycosides & ++ & ++ & $605.51 \pm 0.11$ & $613.63 \pm 0.01$ & $-73.81^{* * *}$ \\
\hline
\end{tabular}

$+=$ present; ++ = highly present; +++ = very highly present

${ }^{*}=$ significantly higher at $\mathrm{P} \leq 0.05 ;{ }^{*}=$ significantly higher at $\mathrm{P} \leq 0.01 ;{ }^{*}=$ significantly higher at $\mathrm{P} \leq 0.001 ;{ }^{\mathrm{N} S}=$ not significantly different at $\mathrm{P} \leq 0.05$

The macroscopic and microscopic examinations of $P$. colocasiae on PDA plate showed no definite pattern. Young mycelia were fluffy and appeared as a pinkish white mass on the surface and reddish at the reverse side of the plate. The microscopic examination of the slide revealed the presence of ovoid to ellipsoidal sporangia borne on irregularly branched sporangiophores with hyphal swellings at branch points. Sporangia were semi-papillate and deciduous. Both hyphae and sporangiophores were non-septate (Plates 1 and 2).

White cottony mycelia of $F$. oxysporum were seen on PDA plates. The aerial mycelia were white and purple at the base. The colony grew rapidly, covering the entire plates within 5 days. The conidiophores were short.
The experiment was conducted as a $2 \times 2 \times 6$ factorial laid out in a completely randomized design (CRD) and data collected from the study were subjected to univariate analysis using IBM SPSS Statistics software version 23, and significant means were separated using least significance difference (LSD) at $\mathrm{P} \leq 0.05$.

\section{RESULTS}

The qualitative screening of the phytochemical constituents of the plant extracts showed that all the phytochemicals tested (terpenoids, tannins, alkaloids, saponins, steroids, hydrogen cyanides, flavonoids, phenols and glycosides) were present in different proportions as shown in Table 1 below. However, there was no observable significant difference in the phytochemical content between the ethanolic and methanolic extracts. Quantitatively, methanolic extract of C. odorata recorded significantly higher phytochemical content as compared to ethanolic extract except the hydrogen cyanide (HCN) which was not significantly different (Table 1 ).
Macro conidia were fusiform, slightly curved, pointed at the tips, mostly monoseptate and scattered. Micro conidia were abundant, and ellipsoidal to cylindrical, as well as straight or curved (Plates 3 and 4).

The results of the minimum inhibitory concentration (MIC) of plant extracts against P. colocasiae and F. oxysporum using broth and agar dilution assay were summarized in Tables 2 . The MIC values against $P$. colocasiae and F. oxysporum ranged from $6.25 \mathrm{mg} / \mathrm{ml}$ to $50 \mathrm{mg} / \mathrm{ml}$ across both assay methods and extracts. The methanolic extract recorded the lowest MIC value (6.25 $\mathrm{mg} / \mathrm{ml}$ ) on $F$. oxysporum using broth dilution assay method while ethanolic extract MIC value of 66.25 $\mathrm{mg} / \mathrm{ml}$ ) on $F$. oxysporum using broth dilution assay was low (Table 2). 


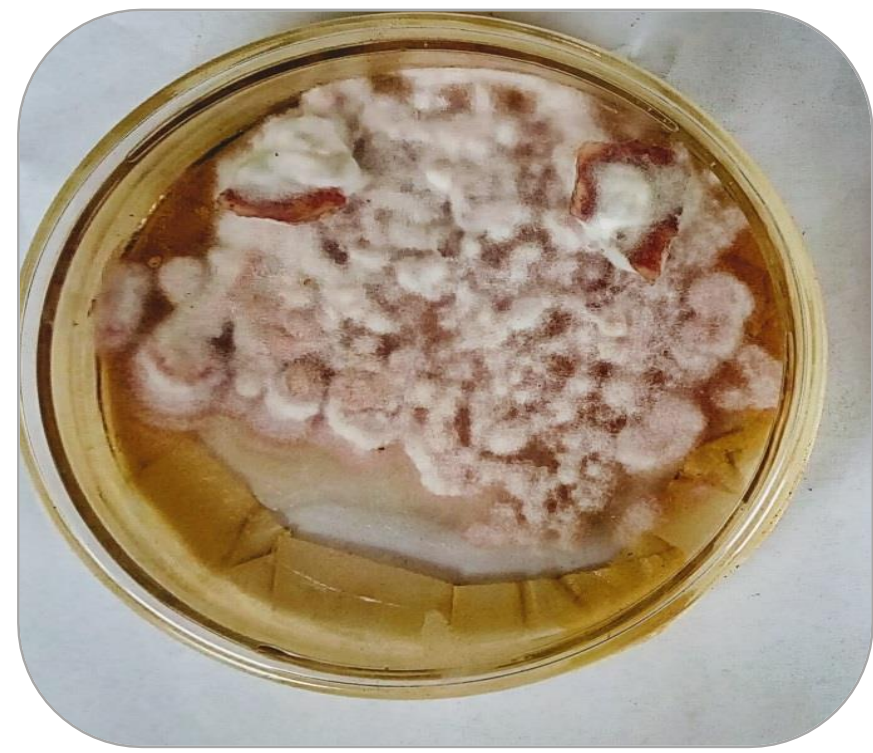

Plate 1. Morphology of P. colocasiae

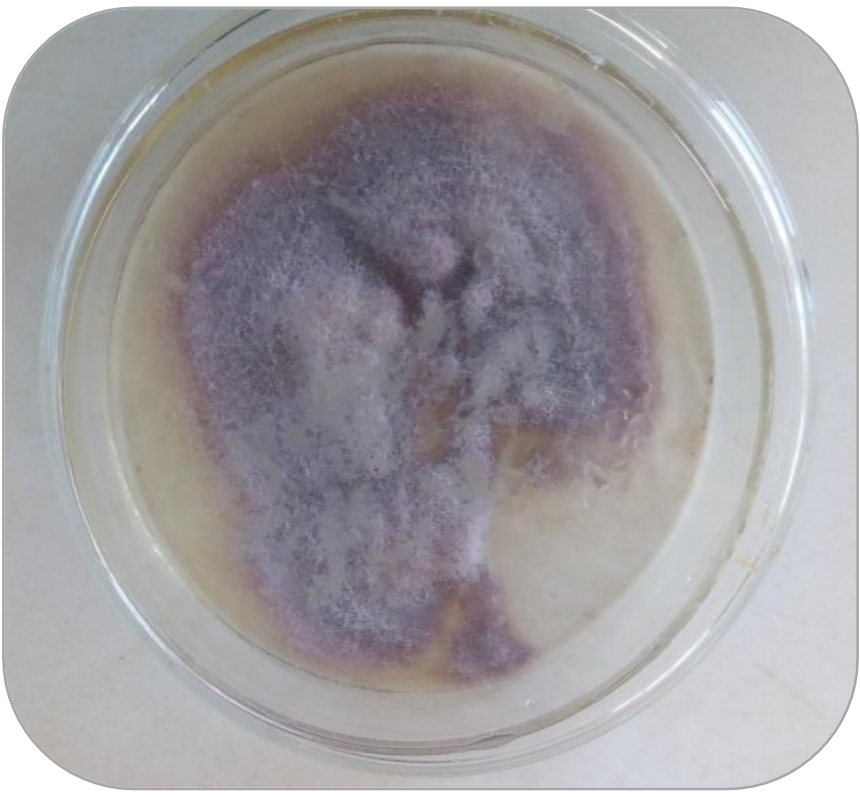

Plate 3. Morphology of $F$. oxysporum

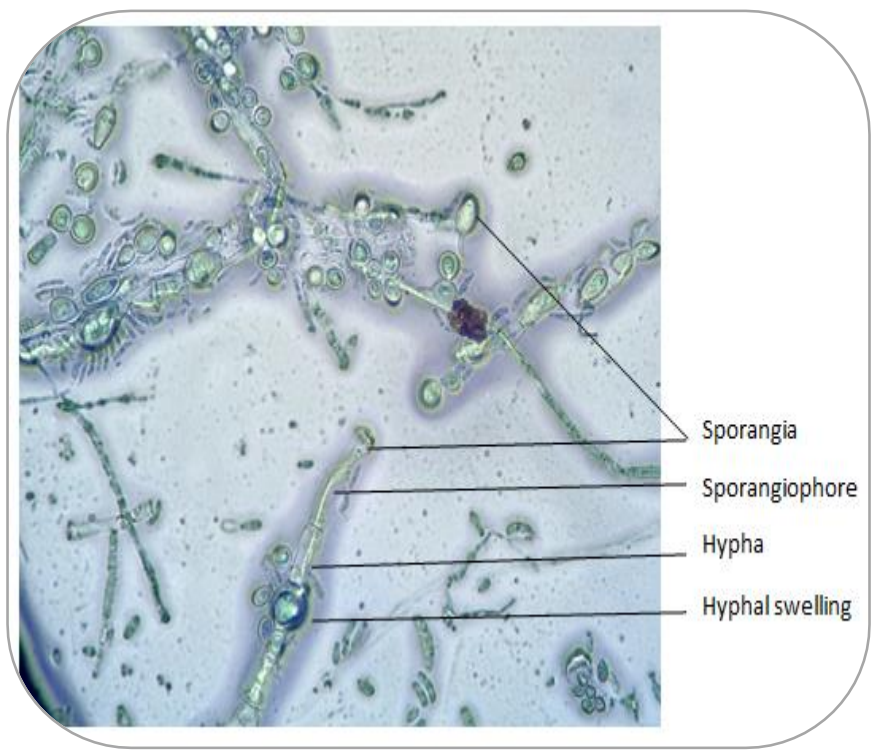

Plate 2. Photomicrograph of P. colocasiae (x400)

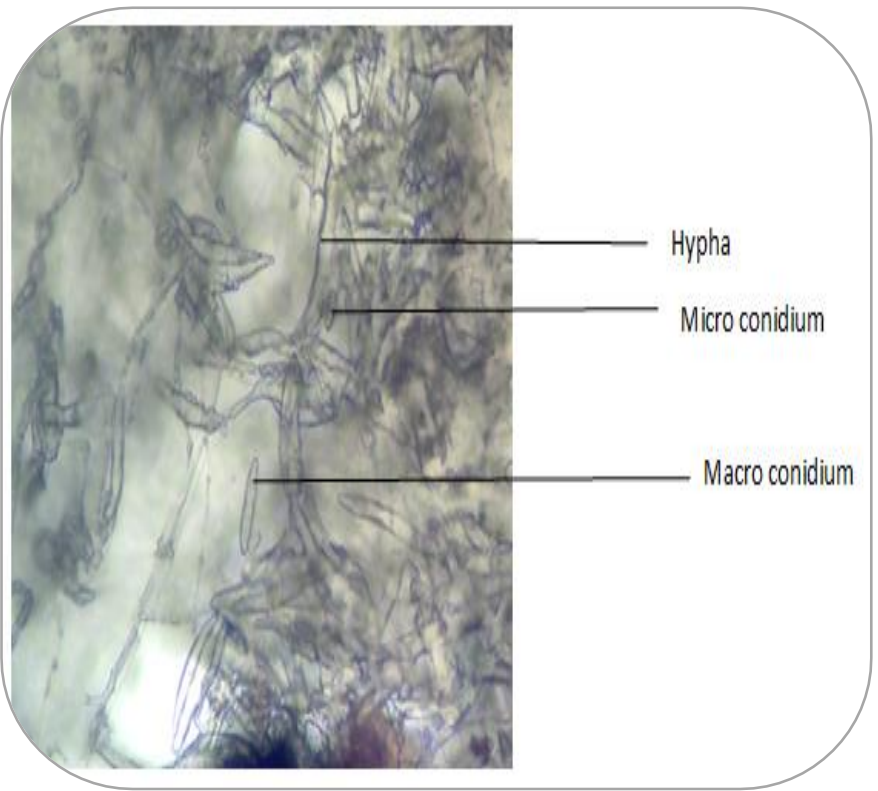

Plate 4. Photomicrograph of F. oxysporum(x400)

Table 2. Minimum inhibitory concentration (MIC) of Chromolaena odarata leaf extracts against Phytophthora colocasiae and Fusarium oxysporum using broth and agar dilution assay

\begin{tabular}{llcc}
\hline Assay method & \multicolumn{1}{c}{ Organisms } & Ethanol extract $(\mathrm{mg} / \mathrm{ml})$ & Methanol extract $(\mathrm{mg} / \mathrm{ml})$ \\
\hline \multirow{2}{*}{ Broth dilution } & Phytophthora colocasiae & 25 & 50 \\
& F. oxysporum & 50 & 6.25 \\
Agar dilution & Phytophthora colocasiae & 12.5 & 50 \\
& F. oxysporum & 6.25 & 25 \\
\hline
\end{tabular}

The result as presented in Table 3 reveals that the inhibition zone diameter (IZD) in P. colocasiae plate was significantly wider $(\mathrm{P}<0.05)$ using disc assay method than the well method. On the other hand, ethanol extract significantly $(\mathrm{P}<0.05)$ inhibited $F$. oxysporum as compared to methanol extract. The different concentrations of $C$. odorata did not show significant difference $(\mathrm{P}<0.05)$ in the IZD of $P$. colocasiae but the IZD of $F$. oxysporum were significantly $(\mathrm{P}<0.05)$ with lower concentration of $C$. odorata leaves extracts $(6.25 \mathrm{mg} / \mathrm{ml})$ than 50 and 100 $\mathrm{mg} / \mathrm{ml}$ (Table 3). The combined effect of the extract and assay method reveals that combining ethanol extract of $C$. odorata with disc assay will effectively inhibit both $P$. colocasiae and F. oxysporum (Table 4). 
Table 3. Mean effect of Assay method, Extract and concentration of Chromolaena odarata on Inhibition Zone Diameter of Phytophthora colocasiae and Fusarium oxysporum

\begin{tabular}{|c|c|c|c|}
\hline & & Phytophthora colocasiae & Fusarium oxysporum \\
\hline \multicolumn{4}{|c|}{ Assay method } \\
\hline $\begin{array}{l}\text { Disc } \\
\end{array}$ & & $16.78 \pm 1.09^{*}$ & $16.22 \pm 1.38$ \\
\hline Well & & $13.03 \pm 1.40$ & $16.12 \pm 1.33$ \\
\hline \multicolumn{4}{|l|}{ Extract } \\
\hline Methanol & & $14.03 \pm 1.31$ & $13.95 \pm 1.41$ \\
\hline Ethanol & & $15.78 \pm 1.26$ & $18.39 \pm 1.17^{*}$ \\
\hline \multicolumn{4}{|c|}{ Concentration } \\
\hline Control & & $30.08 \pm 0.50^{\mathrm{a}}$ & $30.00 \pm 0.49^{\mathrm{a}}$ \\
\hline $100 \mathrm{mg} / \mathrm{ml}$ & & $10.11 \pm 1.09 \mathrm{~b}$ & $10.23 \pm 1.18^{c}$ \\
\hline $50 \mathrm{mg} / \mathrm{ml}$ & & $12.48 \pm 1.35^{b}$ & $10.13 \pm 0.98^{c}$ \\
\hline $25 \mathrm{mg} / \mathrm{ml}$ & & $12.00 \pm 1.10^{\mathrm{b}}$ & $14.50 \pm 2.27 \mathrm{bc}$ \\
\hline $12.5 \mathrm{mg} / \mathrm{ml}$ & & $13.08 \pm 1.29 \mathrm{~b}$ & $14.75 \pm 0.88^{\mathrm{bc}}$ \\
\hline $6.25 \mathrm{mg} / \mathrm{ml}$ & & $11.67 \pm 0.53^{\mathrm{b}}$ & $17.42 \pm 1.35^{\mathrm{b}}$ \\
\hline \multicolumn{4}{|l|}{ LSD } \\
\hline \multicolumn{4}{|c|}{$\begin{array}{l}\text { *-significant higher mean; means with different alphabets along each vertical array represents significant difference } \\
\text { Table 4. Combine mean effect of extract and assay method on Inhibition Zone Diameter of Phytophthora colocasiae and } \\
\text { Fusarium oxysporum }\end{array}$} \\
\hline & & Phytophthora colocasiae & Fusarium oxysporum \\
\hline \multirow{2}{*}{ Methanol } & Disc & $15.67 \pm 1.60^{\mathrm{ab}}$ & $12.78 \pm 1.94^{b}$ \\
\hline & Well & $12.40 \pm 2.05^{\mathrm{b}}$ & $15.13 \pm 2.08^{\mathrm{ab}}$ \\
\hline \multirow{2}{*}{ Ethanol } & Disc & $17.89 \pm 1.49^{a}$ & $19.67 \pm 1.63^{a}$ \\
\hline & Well & $13.67 \pm 1.95^{\mathrm{ab}}$ & $17.11 \pm 1.67^{a b}$ \\
\hline
\end{tabular}

means with different alphabets along each vertical array represents significant difference

The combined effects between extract concentration and assay method are presented in Table 5. From the result, there was no significant difference in the IZD of $P$. colocasiae between the controlled concentration and the two extracts and assay methods used. Similarly, $12.5 \mathrm{mg} / \mathrm{ml}$ of ethanol extract recorded the widest inhibition zone of $15.33 \pm 2.01$ which was not significantly higher than other concentration induced IZDs. However, $25 \mathrm{mg} / \mathrm{ml}$ ethanol extract induced significantly $(\mathrm{P}<0.05)$ wider IZD on $F$. oxysporum than 50 and $100 \mathrm{mg} / \mathrm{ml}$ methanol and ethanol extracts concentrations.
Furthermore, $6.25 \mathrm{mg} / \mathrm{ml}$ with well assay and $25 \mathrm{mg} / \mathrm{ml}$ with disc assay induced wider IZD of $19.83 \pm 1.45$ and $17.83 \pm 3.95$ respectively (Table 5 ). Generally, there was a decrease in IZD across all concentrations of the extract as compared to the control. However, $6.25 \mathrm{mg} / \mathrm{ml}$ methanol extract in well assay method inhibited $F$. oxysporum more after the control with a diameter of $20.67 \pm 0.67$ (Table 6). While $50 \mathrm{mg} / \mathrm{ml}$ ethanol extract in disc assay method inhibited $P$. colocasiae more after the control with a diameter of $19.00 \pm 0.00$.

Table 5. Combine mean effects between concentrations with extract and assay method on Inhibition Zone Diameter of Phytophthora colocasiae and Fusarium oxysporum

\begin{tabular}{|c|c|c|c|c|}
\hline & \multicolumn{2}{|c|}{ Phytophthora colocasiae } & \multicolumn{2}{|c|}{ Fusarium oxysporum } \\
\hline & \multicolumn{4}{|c|}{ Extract } \\
\hline & Methanol & Ethanol & Methanol & Ethanol \\
\hline Control & $30.33 \pm 0.80^{\mathrm{a}}$ & $29.83 \pm 0.65^{\mathrm{a}}$ & $30.00 \pm 0.73^{a}$ & $30.00 \pm 0.73^{\mathrm{a}}$ \\
\hline $100 \mathrm{mg} / \mathrm{ml}$ & $10.23 \pm 1.95^{b}$ & $10.00 \pm 1.21^{b}$ & $7.13 \pm 0.28 \mathrm{e}$ & $13.33 \pm 1.50^{\mathrm{d}}$ \\
\hline $50 \mathrm{mg} / \mathrm{ml}$ & $10.47 \pm 1.22^{b}$ & $14.50 \pm 2.22^{b}$ & $7.92 \pm 0.66^{e}$ & $12.33 \pm 1.36^{\mathrm{d}}$ \\
\hline $25 \mathrm{mg} / \mathrm{ml}$ & $10.33 \pm 0.80^{\mathrm{b}}$ & $13.67 \pm 1.89 \mathrm{~b}$ & $8.50 \pm 0.56^{e}$ & $20.50 \pm 2.84^{b}$ \\
\hline $12.5 \mathrm{mg} / \mathrm{ml}$ & $10.83 \pm 1.11^{b}$ & $15.33 \pm 2.01^{b}$ & $14.33 \pm 1.71^{\mathrm{cd}}$ & $15.17 \pm 0.65^{b c d}$ \\
\hline \multirow[t]{3}{*}{$6.25 \mathrm{mg} / \mathrm{ml}$} & $12.00 \pm 0.37 \mathrm{~b}$ & $11.33 \pm 1.02^{b}$ & $15.83 \pm 2.24 \mathrm{bcd}$ & $19.00 \pm 1.39 \mathrm{bc}$ \\
\hline & \multicolumn{4}{|c|}{ Assay method } \\
\hline & Disc & Well & Disc & Well \\
\hline Control & $30.00 \pm 0.73^{\mathrm{a}}$ & $30.17 \pm 0.75^{a}$ & $30.00 \pm 0.73^{a}$ & $30.00 \pm 0.73^{a}$ \\
\hline $100 \mathrm{mg} / \mathrm{ml}$ & $13.50 \pm 0.76^{b}$ & $6.73 \pm 0.31^{b}$ & $9.92 \pm 1.28^{\mathrm{ef}}$ & $10.55 \pm 2.12^{\text {def }}$ \\
\hline $50 \mathrm{mg} / \mathrm{ml}$ & $15.83 \pm 1.47 \mathrm{~b}$ & $9.13 \pm 1.18^{b}$ & $10.42 \pm 1.67 \mathrm{def}$ & $9.83 \pm 1.19 f$ \\
\hline $25 \mathrm{mg} / \mathrm{ml}$ & $12.67 \pm 0.71^{b}$ & $11.33 \pm 2.16^{b}$ & $17.83 \pm 3.95^{b c}$ & $11.17 \pm 1.64^{d}$ \\
\hline $12.5 \mathrm{mg} / \mathrm{ml}$ & $15.83 \pm 1.54 \mathrm{~b}$ & $10.33 \pm 1.38^{b}$ & $14.17 \pm 1.05^{\text {cdef }}$ & $15.33 \pm 1.48^{\mathrm{bcd}}$ \\
\hline $6.25 \mathrm{mg} / \mathrm{ml}$ & $12.83 \pm 0.40^{\mathrm{b}}$ & $10.50 \pm 0.72^{b}$ & $15.00 \pm 1.88^{b c d e}$ & $19.83 \pm 1.45^{\mathrm{b}}$ \\
\hline
\end{tabular}

means with different alphabets along each vertical and horizontal array for each organism represents significant difference 
Table 6. Effects of concentration, extract and assay method combination on inhibition Zone Diameter of Phytophthora colocasiae and Fusarium oxysporum

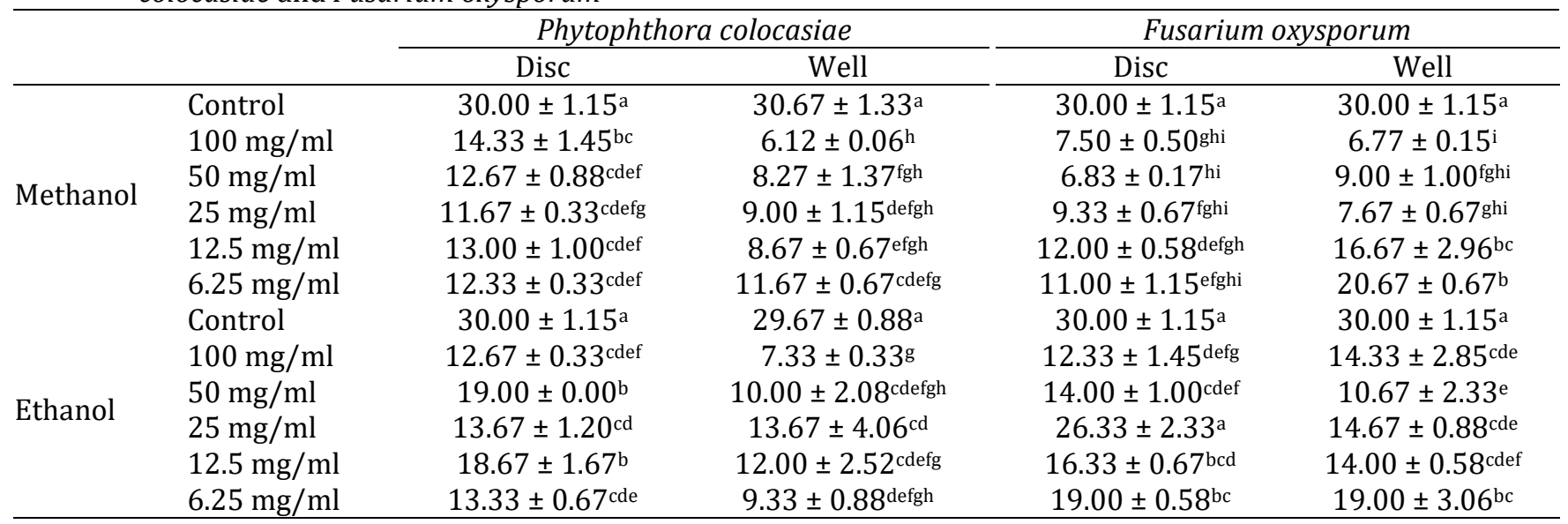

means with different alphabets along each vertical and horizontal array for each organism represents significant difference

\section{DISCUSSION}

These results obtained from the phytochemical analyses of ethanolic and methanolic extracts of C. odorata revealed the presence of alkaloids, saponins, tannins, phenols, flavonoids terpenoids, steroids, hydrogen cyanide and glycosides. Similar bioactive constituents have been reported in the leaf extracts of different plants (Okwu and Joshia, 2006; Eze and Ezejiofor, 2014). The result showed that the methanolic extract had the highest production of phytochemicals than the ethanolic extracts except for hydrogen cyanide. According to Moonmun et al. (2017), the likely contributing factor to differences in phytoconstituents could be as a result of a change in solvent, method of extraction and influence of geographical region from which the plant was collected. The presence of these bioactive substances has been reported to confer resistance to plants against bacteria, fungi and pests (Piasecka et al., 2015) Thus, the antifungal property of $C$. odorata are primarily due to the presence of these phytochemicals, hence this therefore explains the demonstration of the antifungal activities by plants used in this study.

C. odorata contain fungitoxic compounds since they were able to inhibit the growth diameter of the test pathogens. This agrees with earlier reports of several workers on different fungal organisms (Mandalet al., 2007; Witayapan and Sombat, 2007; Okigbo et al., 2009; Bukar et al., 2010; Ijato et al., 2010). The ethanol and methanol extracts inhibition against $F$. oxysporum varied significantly. According to Abayhne and Chauhan, (2016), some plants may have different antimicrobial activity in different solvents. The possible reason may be that each plant contains different components in the form of secondary metabolites that have a different characteristic effect in various solvents which varies on the basis of physical and chemical properties. These properties have different modes of action on different microbes and may results in variable results This agrees with earlier reports of several workers on different solvents (Sen and Batra, 2012; Bassey et al., 2013 and Kalpana et al., 2013).

The findings showed that the antimicrobial activity of $C$. odorata extracts were dependent upon the assay method used. Both assay methods tested were effective in determining the antimicrobial activity of the plant extracts under study. In comparing these results, the inhibition zones for the disc diffusion assay were greater against $P$. colocasiae while well diffusion assay were greater against $F$. oxysporum. Generally, the well diffusion assay had lower inhibition zones for each of the plant extracts tested. This agrees with the work of King and Dykes (2008) that revealed that the well diffusion assay hindered diffusion of each of their test agents used to a larger extent, probably because the agents are not initially in direct contact with the organism but must first diffuse into the agar to exert an antimicrobial effect. Dimethyle sulphoxide (DMSO) was utilized as a negative control because it was used as a solvent in dissolving the extracts. DMSO showed no significant effect on the growth of $F$. oxysporum and $P$. colocasiae. Fluconazole were used as the positive control and recorded the highest inhibition zone diameter against $F$. oxysporum and P. colocasiae.

Conclusively, this study has shown that agar disc 
diffusion assay proved to be more sensitive than well diffusion assay. Since disc diffusion method is easy and rapid to perform, it can be adapted for the routine antifungal susceptibility testing of fungi in clinical laboratories. The variability shown when different susceptibility testing methods were used suggests the need to apply multiple methods when conducting in vitro antimicrobial testing of plant extracts since a single assay method may result in misleading conclusions. This study demonstrated that when a diffusion method is used, multiple concentrations of the agent must be assayed to ensure that a relationship exists between the concentration of the agent and the inhibition zone size. When a relationship does not exist, antimicrobial activity should be determined by a quantitative dilution technique.

\section{ACKNOWLEDGEMENT}

The authors wish to thank the services of Mr. Eugene Ojua for the statistical analysis and contributions in developing this manuscript.

\section{REFERENCES}

Abayhne, M. and N. Chauhan. 2016. Antifungal Activity of Various Medicinal Plants against Late Blight of Potato from Ethiopia. Journal of Scientific Research and Reports, 12: 1-9.

Agrios, G. 2005. Plant pathology. Edition 5th Academic Press, New York, United States of America. 922 p. End of the English version.

Anukwuorji, C., C. Obianuju, R. Ezebo and C. Anuagasi. 2016. Antimicrobial Effects of Four Plant Extracts against Post Harvest Spoilage Fungi of Yam (Dioscorea rotundata Poir). International Journal of Plant \& Soil Science, 12: 1-10.

Balouiri, M., M. Sadiki and S. K. Ibnsouda. 2016. Methods for in vitro evaluating antimicrobial activity: A review. Journal of Pharmaceutical Analysis, 6: 7179.

Bassey, I., F. Ogbemudia, K. Harold and K. Idung. 2013. Combined antifungal effects of extracts of Jatropha curcas and Chromolaena odorata on seed borne fungi of Solanum gilo Raddi. Bulletin of Environment, Pharmacology and Life Sciences, 2: 13-17.

Bukar, A., A. Uba and T. Oyeyi. 2010. Antimicrobial profile of moringa oleifera lam. Extracts against some food - borne microorganisms. Bayero Journal of Pure and Applied Sciences, 3: 43-48.

Chiejina, N. 2008. Mycoflora of some salad vegetables.
Bio-research, 6: 392-395.

Divya Rani, V. and H. Sudini. 2013. Management of soilborne diseases in crop plants: an overview. International Journal of Plant, Animal and Environmental Sciences, 3: 156-164.

Doherty, F. V., O. O. Olaniran and K. U.C. 2010. Antimicrobial Activities of Aframomum Melegueta (Alligator Pepper). International Journal of Biology, 2: 126-131.

Dugan, F. M. and F. M. Dugan. 2006. The identification of fungi: an illustrated introduction with keys, glossary, and guide to literature. American Phytopathological Society Publications, USA.

Eze, C. S and A. J. Ezejiofor, 2014.Phytochemial screening of Acanthus montanus (Nees) T. Anderson and Criniumjagus (Thomps) extracts and their potential for controlling rot fungi of stored cocoyam (Colocasia esculenta (L.) Schott. International Journal of Engineering Sciences and Research Technology, 3: 659 - 665.

Gawai, D. 2015. Antifungal activity of essential oil of Cymbopogon citratus stap against different Fusarium species. Bionano Frontier, 8: 186-189.

Gurjar, M. S., S. Ali, M. Akhtar and K. S. Singh. 2012. Efficacy of plant extracts in plant disease management. Agricultural Sciences 3: 425-433.

Ijato, J., S. Oyeyemi, J. Ijadunola and J. Ademuyiwa. 2010. Alleopathic effects of leaf extract of Azadirachta indica and Chromolaena odorata against postharvest and transit rot of tomato (Lycopersicon esculentum L.). Journal of American Science, 6: 1595-1599.

Joshi, M., R. Srivastava, A. K. Sharma and A. Prakash. 2013. Isolation and characterization of Fusarium oxysporum, a wilt causing fungus, for its pathogenic and non-pathogenic nature in tomato (Solanum lycopersicum). Journal of Applied and Natural Science, 5: 108-117.

Kalpana, S., S. Moorthi and S. Kumara. 2013. Antimicrobial activity of different extracts of leaf of Moringa oleifera (Lam) against gram positive and gram negative bacteria. International Journal of Current Microbiology and Applied Sciences, 2: 514-518.

King, T., G. Dykes and R. Kristianti. 2008. Comparative Evaluation of Methods Commonly Used to Determine Antimicrobial Susceptibility to Plant Extracts and Phenolic Compounds. Journal of 
AOAC International, 91: 1423-1429.

Mondal, K., S. Dey and B. Pati. 2007. Antimicrobial activity of the leaf extracts of Hyptis suaveolens (L.) poit. Indian Journal of Pharmaceutical Sciences, 69: 568.

Moonmun, D. 2017. Quantitative Phytochemical Estimation and Evaluation of Antioxidant and Antibacterial Activity of Methanol and Ethanol Extracts of Heliconia rostrata. Indian Journal of Pharmaceutical Sciences, 79: 79-90.

Nantitanon, W. 2007. Antioxidant and Antimicrobial Activities of Hyptis suaveolens Essential Oil. Scientia Pharmaceutica, 75: 35-46.

Ohikhena, F. U., O. A. Wintola and A. J. Afolayan. 2017. Evaluation of the Antibacterial and Antifungal Properties of Phragmanthera capitata (Sprengel) Balle (Loranthaceae), a Mistletoe Growing on Rubber Tree, Using the Dilution Techniques. The Scientific World Journal, 2017: 1-8.

Okigbo, R. N., R. E. Okorie and R. R. Putheti. 2009. In vitro effects of garlic (Allium sativum L.) and African basil (Ocimum gratissimum L.) on pathogens isolated from rotted cassava roots. Interciencia, 34: $742-747$.

Okwu, D. E. and C. Josiah. 2006. Evaluation of the chemical composition of two Nigerian medicinal plants. African Journal of Biotechnology, 5: 357361.

Othman, M., H. S. Loh, C. Wiart, T. J. Khoo, K. H. Lim and
K. N. Ting. 2011. Optimal methods for evaluating antimicrobial activities from plant extracts. Journal of Microbiological Methods, 84: 161-166.

Pachkore, G., D. Dhale and A. Dharasurkar. 2011. Antimicrobial and phytochemical screening of Hyptis suaveolens (L. Poit) L amiaceae. International Multidisciplinary Research Journal, 1: $1-3$.

Piasecka, A., N. Jedrzejczak-Rey and P. Bednarek. 2015. Secondary metabolites in plant innate immunity: conserved function of divergent chemicals. New Phytologist, 206: 948-964.

Ramaiah, A. K. and R. K. H. Garampalli. 2015. In vitro antifungal activity of some plant extracts against Fusarium oxysporum f. sp. lycopersici. Asian Journal of Plant Science and Research, 5: 22-27.

Sen, A. and A. Batra. 2012. Evaluation of antimicrobial activity of different solvent extracts of medicinal plant: Melia azedarach L. International Journal of Current Pharmaceutical Research, 4: 67-73.

Sousa, Z., F. de Oliveira, A. da Conceição, L. A. Silva, M. Rossi, J. d. Santos and J. Andrioli. 2012. Biological activities of extracts from Chenopodium ambrosioides Lineu and Kielmeyera neglecta Saddi. Annals of Clinical Microbiology and Antimicrobials, 11: 20.

Webster, J. M. 1970. George N. AGRIOS: Plant Pathology. Academic Press, New York, 1969: 629 p. \$14.00. Nematologica, 16: 158.
Contribution of Authors:

Augusta Okoro

Chiemeka Onaebi
: Conduct research and write manuscript and data analysis

: Reviewed manuscript and help in conducting research 